\title{
Fluid sample injectors for x-ray free electron laser at SACLA
}

\author{
Kensuke Tono ${ }^{1,2}$ \\ ${ }^{1}$ Japan Synchrotron Radiation Research Institute, 1-1-1 Kouto, Sayo, Hyogo 679-5198, Japan \\ ${ }^{2}$ RIKEN SPring-8 Center, 1-1-1 Kouto, Sayo, Hyogo 679-5148, Japan \\ (Received 29 October 2016; revised 10 January 2017; accepted 8 February 2017)
}

\begin{abstract}
This paper provides a review on sample injectors which are provided at SPring-8 Angstrom Compact free electron LAser (SACLA) for conducting serial measurement in a 'diffract-before-destroy' scheme using an x-ray free electron laser (XFEL). Versatile experimental platforms at SACLA are able to accept various types of injectors, among which liquidjet, droplet and viscous carrier injectors are frequently utilized. These injectors produce different forms of fluid targets such as a liquid filament with a diameter in the order of micrometer, micro-droplet synchronized to XFEL pulses, and slowly flowing column of highly viscous fluid with a rate below $1 \mu \mathrm{L} \mathrm{min}{ }^{-1}$. Characteristics and applications of the injectors are described.
\end{abstract}

Keywords: SACLA; sample injector; serial femtosecond crystallography; x-ray free electron laser

\section{Introduction}

An $\mathrm{x}$-ray free electron laser (XFEL) is a high power $\mathrm{x}$ ray source which produces laser light with a wavelength of the order of angstrom. The first two XFEL facilities in the world, the Linac Coherent Light Source (LCLS) and SPring-8 Angstrom Compact free electron LAser (SACLA), provide femtosecond $\mathrm{x}$-ray pulses with peak powers of the order of tens of $\mathrm{GW}^{[1,2]}$. By focusing the XFEL pulse to $\sim 1 \mu \mathrm{m}(\sim 0.05 \mu \mathrm{m})$, the intensity reaches as high as $\sim 10^{18}$ $\left(\sim 10^{20}\right) \mathrm{W} \mathrm{cm}^{-2[3,4]}$. These characteristics offer research opportunities in various fields of science such as structural biology ${ }^{[5-9]}$, nonlinear x-ray optics ${ }^{[10,11]}$, ultrafast physics and chemistry ${ }^{[12-15]}$, and high energy density science ${ }^{[16]}$.

One of the most important targets of XFEL applications is damage-free structure analysis in a 'diffract-before-destroy' scheme ${ }^{[17,18]}$, in which diffraction events in the sample can be terminated before structural change is initiated ${ }^{[19]}$. A diffraction pattern of the sample can be recorded even under the irradiation of an XFEL pulse with an intensity higher than the damage threshold. However, as the sample is to be destroyed after the irradiation, a new sample has to be delivered before the next $\mathrm{x}$-ray pulse comes to the interaction point. For this purpose, fluid sample injectors have been developed.

Correspondence to: K. Tono. XFEL Utilization Division, Japan Synchrotron Radiation Research Institute, 1-1-1 Kouto, Sayo, Hyogo 6795198, Japan. Email: tono@spring8.or.jp
In the early experiments with XFEL, liquid-jet injectors using a gas dynamic virtual nozzle (GDVN) were applied to protein crystallography $[5,7,20-23]$. This type of injector produced a continuous stream of liquid containing $10^{8}-$ $10^{9} \mathrm{~cm}^{-3}$ of protein microcrystals ${ }^{[20,21]}$. A series of diffraction patterns from the crystal suspension were recorded with femtosecond $\mathrm{x}$-ray pulses in a pulse by pulse manner. This method is called serial femtosecond crystallography (SFX). Because the liquid-jet injectors worked at a typical flow rate of the order $10 \mu \mathrm{L} \mathrm{min}^{-1}$, the early SFX experiments consumed protein crystals in the order of 10-100 $\mathrm{mg}$.

To reduce the sample consumption, different injectors have been developed primarily for the application to SFX. A lipidic-cubic-phase (LCP) injector produces a slow flow of highly viscous lipid containing microcrystals at a flow rate of $10^{-3}-10^{-1} \mu \mathrm{L} \mathrm{min} \min ^{-124-26]}$. A typical sample amount required for collecting a full dataset can be as small as $1 \mathrm{mg}$. Alternative crystal carriers have been utilized not only for insoluble proteins but also for soluble ones ${ }^{[25,27-29]}$. An electrospun injector produces a liquid jet in an electric field to deliver a crystal suspension at a low flow rate of $0.14-3.1 \mu \mathrm{L} \mathrm{min}{ }^{-1[30]}$. Recently drop-on-demand injectors have been applied to SFX experiments under the atmospheric pressure ${ }^{[31,32]}$. This type of injector delivers crystal-containing droplets in synchronization with XFEL pulses. In contrast to the continuous-flow injectors, the pulsed operation of the injector can help to reduce the sample consumption. 
The success of SFX in the initial stage has led to developments of injection methods for chemically activated timeresolved SFX. A mix-and-jet injector enables rapid mixing of a reactant solution and a crystal suspension in a timescale of millisecond for capturing protein motion initiated by chemicals $^{[33,34]}$.

Also frequently used are injectors which are appropriate for gas-phase samples and homogeneous solutions. An aerosol injector has been employed to deliver isolated particles into a vacuum for coherent diffraction imaging (CDI) with extremely low background signals ${ }^{[6,35]}$. Solution samples for $\mathrm{x}$-ray spectroscopy and wide-angle x-ray scattering are often provided by a liquid-jet injector which creates a sheet of liquid ${ }^{[12,14]}$.

This paper provides a review on fluid sample injectors at SACLA. The XFEL beamline (BL3) of SACLA produces hard X-ray pulses with peak powers of 6-60 GW, durations shorter than $10 \mathrm{fs}$ (full width at half maximum) and photon energies of 4-20 $\mathrm{keV}^{[2,36-38]}$. The fluid sample injectors have been playing central roles in experiments using the 'diffract-before-destroy' approach, especially in $\mathrm{SFX}^{[27,39-42]}$. The next section gives short descriptions on experimental instruments to which the fluid injectors are often installed. The specifications and applications of four kinds of injectors are described in the third section. The final section is devoted to summary and future perspectives.

\section{Experimental platforms with fluid injectors}

\subsection{DAPHNIS for SFX}

Fluid injectors are installed to experimental systems at the end stations of XFEL beamlines (BL2 and BL3). Diverse Application Platform for Hard x-ray Diffraction in SACLA (DAPHNIS) is a system for serial diffraction/scattering experiments under atmospheric pressure. Its detailed description is found in Ref. [43]. Figure 1 shows a standard setup of DAPHNIS, which consists of a sample chamber, microscopes for sample monitoring, and a multi-port charge-coupled-device (MPCCD) detector with eight sensor modules ${ }^{[44]}$. The chamber is filled with $\mathrm{He}$ gas, a partial pressure of which is kept higher than 0.9 atm during measurement. The atmospheric-pressure operation helps stable fluid injection, rapid sample exchange, and temperature control of the sample. The injectors are mounted on motorized stages to be positioned properly to the interaction point. The four kinds of standard injectors at SACLA are fully compatible with DAPHNIS (see Section 3). In addition, DAPHNIS can be easily customized to accept other injection methods such as electrospun liquid microjet and fast mixing liquid jet. This flexibility is useful to users who bring their own injectors into SACLA.

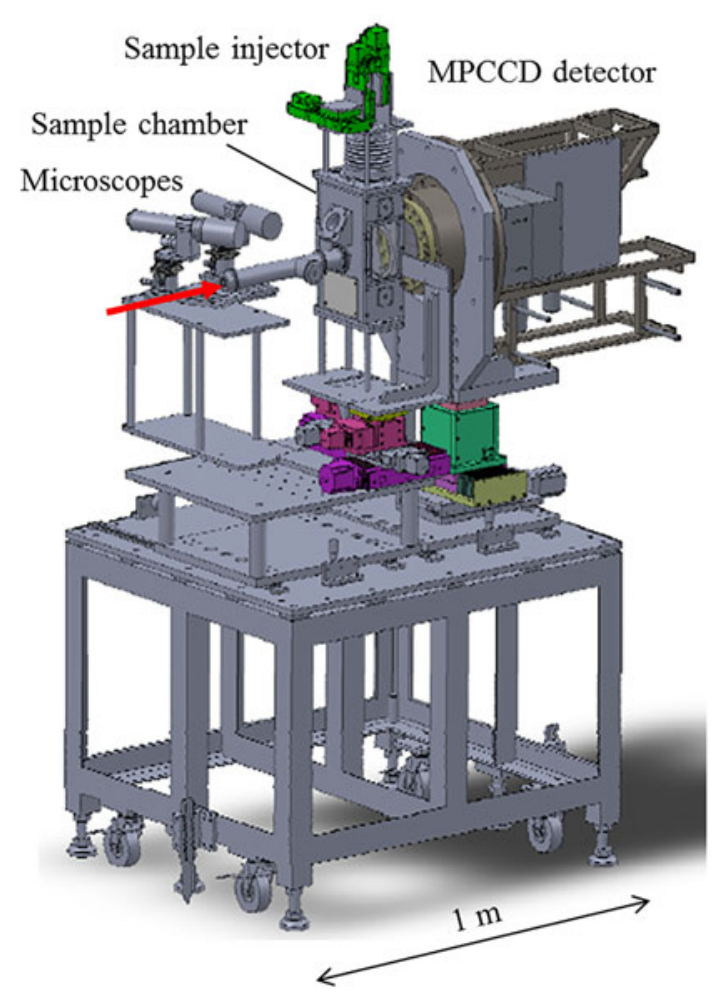

Figure 1. Standard setup of DAPHNIS for serial diffraction/scattering experiments $^{[43]}$. The DAPHNIS system consists of a sample chamber, microscopes for sample monitoring, a sample injector, and an MPCCD detector with eight sensor modules. These key components are built on a single table. The sample chamber is filled with a $\mathrm{He}$ gas during measurement. The red arrow indicates the XFEL beam direction.

\subsection{MAXIC for $C D I$}

Figure 2 shows Multiple Application X-ray Imaging Chamber (MAXIC) which is mostly utilized for CDI in vacuum environment. Detailed descriptions on MAXIC are given in Ref. [45]. In a standard configuration for CDI, the chamber is combined with a focusing system which provides a $1 \mu \mathrm{m}$ spot of $\mathrm{x}$-rays at the sample position ${ }^{[3]}$. The XFEL beam from the focusing system is collimated with a pair of slits on the path to the sample. Diffraction patterns are recorded with the MPCCD detectors. The in-vacuum operation helps to suppress background signals. The liquidjet injector with GDVN and aerosol injector are compatible with MAXIC, although they are not frequently employed in CDI at SACLA. In most cases, specimens are fixed on a thin $\mathrm{Si}_{3} \mathrm{~N}_{4}$ membrane, which is mounted on motorized stages and raster-scanned.

\section{Sample injectors}

\subsection{Liquid-jet injector with GDVN}

The liquid-jet injector with GDVN produces a thin and fast stream of solution or suspension. The basic structure and working principle of GDVN are found in Refs. [46-48]. 


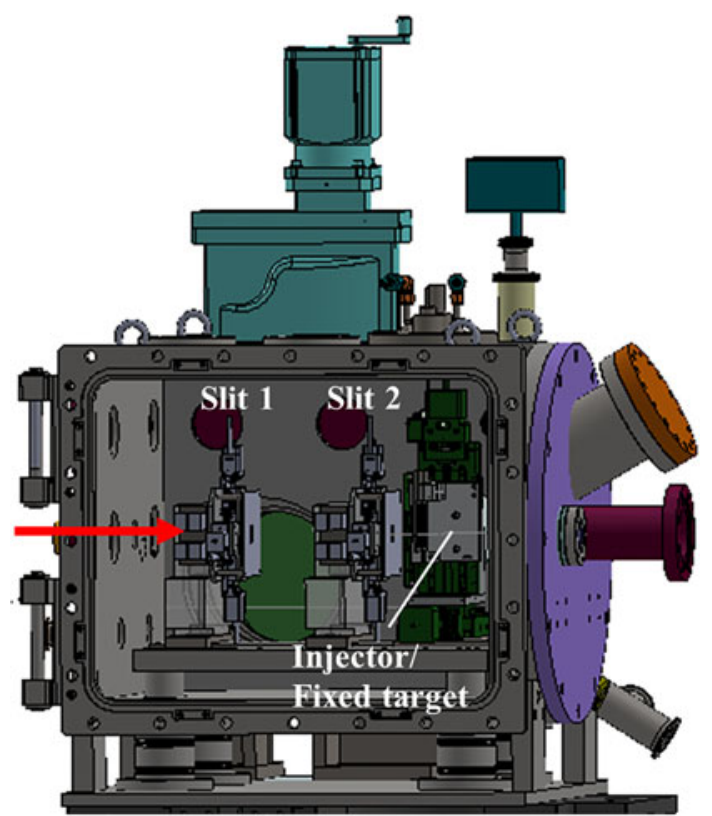

Figure 2. The MAXIC system for in-vacuum diffraction/scattering experiments ${ }^{[45]}$. The vacuum chamber contains a pair of four-jaw slits and motorized stages for injector or fixed targets. In most experiments, a focusing system and MPCCD detectors are employed as well. The red arrow indicates the XFEL beam direction.

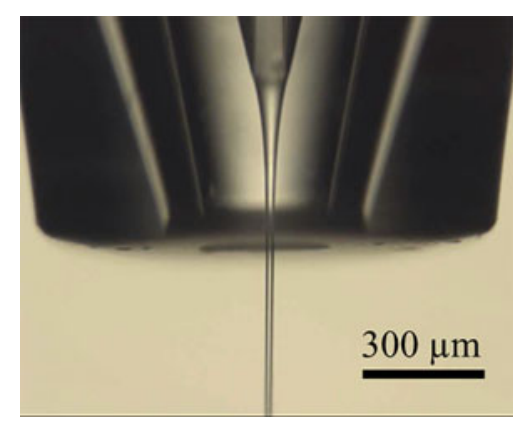

Figure 3. A microscope image of the tip of GDVN at SACLA. The liquid beam from the inner capillary is squeezed by the gas flow in the outer capillary.

Figure 3 shows a microscope image of the tip of GDVN at SACLA. The nozzle has a double capillary structure, in which sample liquid and gas are supplied through the inner and outer capillaries, respectively. The sample liquid is delivered with a hydraulic pump for high performance liquid chromatography (HPLC) pump. The concentric gas flow squeezes the liquid beam to make a thin sample filament, a diameter of which is varied with a flow rate of liquid and a stagnation pressure of He. Table 1 gives diameters of water beam produced by using a center capillary with an inner diameter of $50 \mu \mathrm{m}$. The size of inner capillary should be chosen to match sample properties such as viscosity, and particle size and density in suspension. The standard inner diameters are 50,75, 100 and $150 \mu \mathrm{m}$.

In SFX experiments, the GDVN injector delivers microcrystals dispersed in a buffer solution. Diffraction measure-

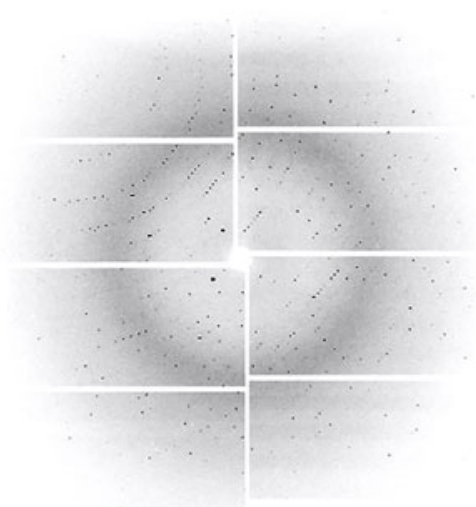

Figure 4. One of the diffraction patterns of $1 \mu \mathrm{m}$ lysozyme crystals delivered by using the liquid-jet injector with GDVN. The image was recorded with the MPCCD detector which was placed $50 \mathrm{~mm}$ apart from the interaction point. Each of the eight sensor modules of the detector has an effective area of $25 \mathrm{~mm} \times 50 \mathrm{~mm}$.

Table 1. Diameter of a water beam from GDVN ${ }^{\mathrm{a}}$ at SACLA ${ }^{[43]}$.

\begin{tabular}{llll}
\hline Water flow rate & \multicolumn{3}{c}{ Liquid-beam diameter $(\mu \mathrm{m})$} \\
\cline { 2 - 4 }$\left(\mu \mathrm{L} \mathrm{min}^{-1}\right)$ & He 0.06 $\mathrm{MPa}^{\mathrm{b}}$ & He 0.10 $\mathrm{MPa}^{\mathrm{b}}$ & $\mathrm{He} 0.16 \mathrm{MPa}^{\mathrm{b}}$ \\
\hline 60 & Unstable & Unstable & 8 \\
80 & Unstable & Unstable & 10 \\
100 & Unstable & Unstable & 11 \\
120 & Unstable & 20 & 13 \\
160 & 32 & 24 & 16 \\
200 & 34 & 28 & 22 \\
240 & 36 & 28 & 22 \\
280 & 38 & 31 & 21 \\
320 & 40 & 32 & 23 \\
\hline
\end{tabular}

${ }^{a}$ An inner diameter of the center capillary is $50 \mu \mathrm{m}$.

${ }^{\mathrm{b}}$ Gauge pressure.

ment is usually performed by using DAPHNIS. Figure 4 shows an x-ray diffraction pattern from a lysozyme microcrystal supplied from a suspension with a crystal density of $\sim 10^{9} \mathrm{~cm}^{-3}$ and an average crystal size of $\sim 1 \mu \mathrm{m}$. A dataset with 3226 diffraction patterns gave a crystal structure at a resolution of $0.24 \mathrm{~nm}^{[43]}$. The GDVN injector has also been applied to in-vacuum serial diffraction experiment using MAXIC ${ }^{[39]}$.

\subsection{Liquid-jet injector with sample circulator}

Another type of liquid-jet injector is utilized to keep sample injection with circulating a sample liquid. Figure 5 shows a schematic drawing of the injector system. The liquid is circulated by using a peristaltic pump. The standard nozzle apertures are 100 and $200 \mu \mathrm{m}$ in diameter. A liquidbeam diameter is almost the same as the aperture size. A typical flow rate is $1.5 \mathrm{~mL} \mathrm{~min}^{-1}\left(2.5 \mathrm{~mL} \mathrm{~min}{ }^{-1}\right)$ with the $100 \mu \mathrm{m}(200 \mu \mathrm{m})$ nozzle. A minimum liquid volume of $\sim 5 \mathrm{~mL}$ is required for the circulator to keep injection. As in the case of GDVN, a microcrystal suspension is 


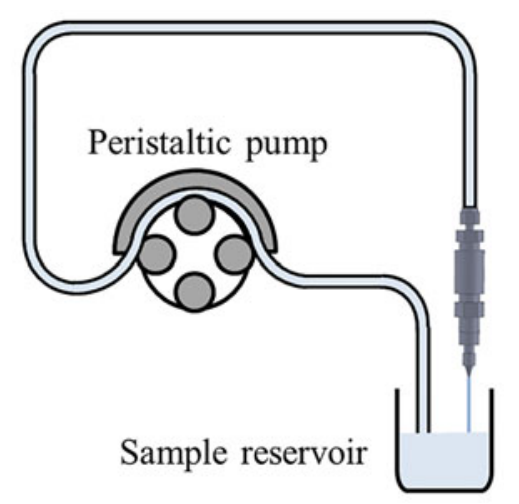

Figure 5. A schematic drawing of the liquid-jet injector with a sample circulator. The sample liquid in the reservoir is discharged and circulated by the peristaltic pump.

delivered in SFX. Although the $100 \mu \mathrm{m}(200 \mu \mathrm{m})$ liquid beam generally produces high background signals, relatively large crystals can make Bragg-signal intensities high enough for solving crystal structures. For example, a crystal structure of lysozyme was determined at a resolution of $0.24 \mathrm{~nm}$ by using $\sim 5 \mu \mathrm{m}$ crystals ejected from the $200 \mu \mathrm{m}$ nozzle ${ }^{[43]}$.

\subsection{Viscous carrier injectors}

The liquid-jet injectors generally consume a large amount of sample because of the high flow rate. This issue is especially serious for SFX users who measure precious protein samples. To reduce the sample consumption, viscous carrier injectors have been developed for the application to SFX. Two types are now available at SACLA. The one is basically a syringe pump (Figure 6), which slowly extrudes a viscous fluid containing microcrystals. The plunger is driven with a linear actuator. A standard syringe needle has an inner diameter of $110 \mu \mathrm{m}$. A typical flow rate is as low as $0.5 \mu \mathrm{Lmin}^{-1}$. A thinner needle with a $50 \mu \mathrm{m}$ inner diameter can be employed to further suppress the flow rate. Temperature of the syringe is kept constant with a thermoelectric device. The combination of this injector with the grease matrix method can lead to a wide range of application ${ }^{[27]}$. Sugahara et al. determined the crystal structures of lysozyme, glucose isomerase, thaumatin and fatty-acid-binding protein type 3 at resolutions of $0.2 \mathrm{~nm}$ or better by using less than $1 \mathrm{mg}$ of the proteins.

The other type of injector is driven by an HPLC pump. Its details will be described in a separate paper ${ }^{[49]}$. Currently this injector is routinely used in SFX with a variety of crystal carriers such as LCP, greases ${ }^{[27]}$, and hyaluronic acid ${ }^{[29]}$. The working principle is essentially the same as that of the LCP injector developed by Weierstall et al. ${ }^{[24]}$.

\subsection{Droplet injector}

The viscous carrier injector has facilitated the delivery of lipophilic samples in lipidic carriers.Although the grease (a)

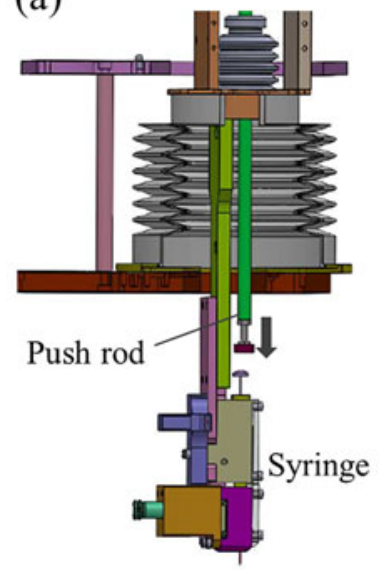

(b)

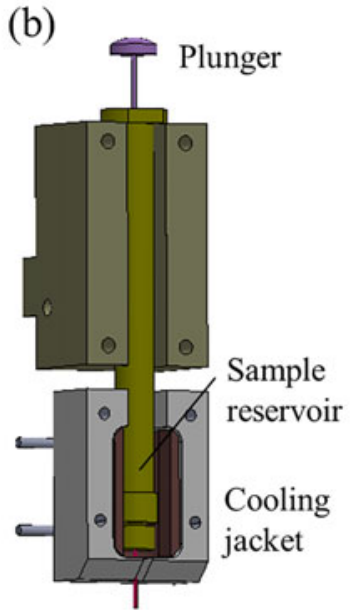

Figure 6. (a) The syringe-pump type of injector for a viscous carrier. The plunger of the syringe is pushed down by the push rod mounted on a linear actuator. (b) Enlarged view of the syringe part. Temperature of the syringe is kept constant by using the cooling jacket with a thermoelectric device.

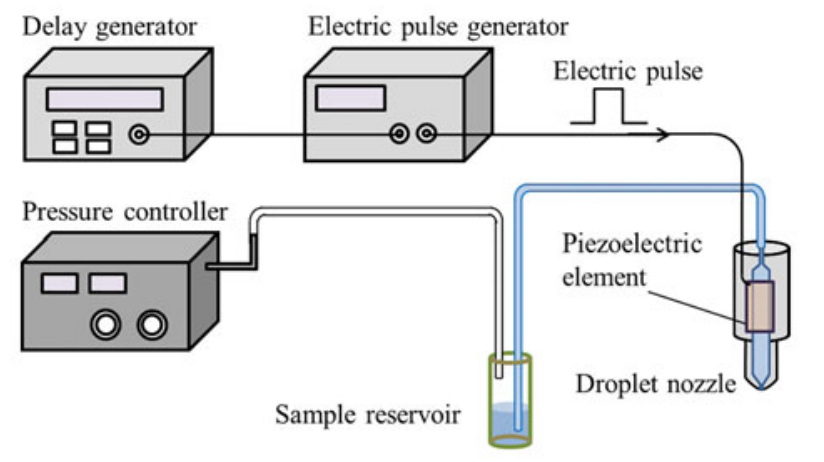

Figure 7. A schematic diagram of the system of droplet injector. The nozzle with a piezoelectric element is driven by the electric pulse generator. The timing of ejection is adjusted by the delay generator which is synchronized with the XFEL source. The pressure controller keeps an optimum pressure of the sample.

matrix method extended the applicability to soluble-protein crystals, it is more or less an invasive method; i.e., a grease carrier can deteriorate sample quality. Pulsed sample injection is a direct method to deliver non-viscous samples with a reasonably small consumption.

The pulsed droplet injector at SACLA produces a drop of sample liquid at a timing synchronized with the XFEL source ${ }^{[31]}$. Figure 7 shows a schematic diagram of the injector system, which basically consists of a nozzle with a piezoelectric element, a sample reservoir, a pressure controller, a delay generator and an electric pulse generator. The piezoelectric element is driven by the electric pulse generator, to which the delay generator provides a timing signal synchronized with the XFEL source. The pressure controller maintains the sample pressure at which the liquid keeps the meniscus at an optimum position of the nozzle tip. The standard nozzle has an aperture of $80 \mu \mathrm{m}$ in diameter. A typical sample flow rate is $0.5 \mu \mathrm{L} \mathrm{min}^{-1}$ at $30 \mathrm{~Hz}$. 
The droplet method was successfully applied to SFX. Mafuné et al. determined the structure of lysozyme at a resolution of $0.23 \mathrm{~nm}$ from crystals with an average size of $\sim 5 \mu \mathrm{m}$. A complete dataset was obtained in $\sim 30 \mathrm{~min}$ with a sample amount less than $0.3 \mathrm{mg}$.

\section{Summary and outlook}

The fluid sample injectors at SACLA have facilitated experiments in the way of 'diffract before destroy' by working with the diverse experimental platforms such as DAPHNIS and MAXIC. They are especially playing a key role in protein SFX using the DAPHNIS system. After the successful demonstrations of the liquid-jet injectors, the viscous carrier injector and the droplet injector expanded the opportunity of SFX to a wide variety of proteins. Now both lipophilic and hydrophilic crystals can be measured with a reasonably small amount.

The increasing demands for SFX lead to the further development of sample delivery methods which will enable data acquisition in a short time with a reduced sample amount. A fixed target method is now capable of delivering crystals at the repetition rates of the existing XFEL sources ${ }^{[50]}$. Microfluidic flow cells would be useful for precious protein samples ${ }^{[51,52]}$. Sample injection with a coaxial sheath liquid can help to suppress a sample amount even in the case of continuous-flow liquid jet ${ }^{[34]}$.

The developments in sample delivery methods add new capabilities to the experimental systems. Time-resolved SFX, for example, is becoming a common technique for studying dynamics of proteins ${ }^{[53,54]}$. In this technique, delivery tools should be compatible with sample activation techniques such as optical pulse irradiation and fast mixing of reactant and sample solutions ${ }^{[33,34]}$.

\section{Acknowledgements}

The author thanks members of the SACLA Science Research Group and the Engineering Team of RIKEN SPring-8 Center for providing the figures and the table in this paper. The experimental data were obtained at BL3 of SACLA with the approval of the Japan Synchrotron Radiation Research Institute (JASRI) (Proposal Numbers 2014B8051, 2015A8047, 2015B8054, 2015B8064 and 2016A8066). The injector developments at SACLA were supported by the X-ray FreeElectron Laser Priority Strategy Program (MEXT); JSPS KAKENHI Grant Number 15K05407.

\section{References}

1. P. Emma, R. Akre, J. Arthur, R. Bionta, C. Bostedt, J. Bozek, A. Brachmann, P. Bucksbaum, R. Coffee, F.-J. Decker, Y. Ding, D. Dowell, S. Edstrom, A. Fisher, J. Frisch, S. Gilevich, J. Hastings, G. Hays, Ph. Hering, Z. Huang, R. Iverson, H. Loos, M. Messerschmidt, A. Miahnahri, S. Moeller, H.-D.
Nuhn, G. Pile, D. Ratner, J. Rzepiela, D. Schultz, T. Smith, P. Stefan, H. Tompkins, J. Turner, J. Welch, W. White, J. Wu, G. Yocky, and J. Galayda, Nat. Photon. 4, 641 (2010).

2. T. Ishikawa, H. Aoyagi, T. Asaka, Y. Asano, N. Azumi, T. Bizen, H. Ego, K. Fukami, T. Fukui, Y. Furukawa, S. Goto, H. Hanaki, T. Hara, T. Hasegawa, T. Hatsui, A. Higashiya, T. Hirono, N. Hosoda, M. Ishii, T. Inagaki, Y. Inubushi, T. Itoga, Y. Joti, M. Kago, T. Kameshima, H. Kimura, Y. Kirihara, A. Kiyomichi, T. Kobayashi, C. Kondo, T. Kudo, H. Maesaka, X. M. Maréchal, T. Masuda, S. Matsubara, T. Matsumoto, T. Matsushita, S. Matsui, M. Nagasono, N. Nariyama, H. Ohashi, T. Ohata, T. Ohshima, S. Ono, Y. Otake, C. Saji, T. Sakurai, T. Sato, K. Sawada, T. Seike, K. Shirasawa, T. Sugimoto, S. Suzuki, S. Takahashi, H. Takebe, K. Takeshita, K. Tamasaku, K. Tono, S. Wu, M. Yabashi, M. Yamaga, A. Yamashita, K. Yanagida, C. Zhang, T. Shintake, H. Kitamura, and N. Kumagai, Nat. Photon. 6, 540 (2012).

3. H. Yumoto, H. Mimura, T. Koyama, S. Matsuyama, K. Tono, T. Togashi, Y. Inubushi, T. Sato, T. Tanaka, T. Kimura, H. Yokoyama, J. Kim, Y. Sano, Y. Hachisu, M. Yabashi, H. Ohashi, H. Ohmori, T. Ishikawa, and K. Yamauchi, Nat. Photon. 7, 43 (2013).

4. H. Mimura, H. Yumoto, S. Matsuyama, T. Koyama, K. Tono, Y. Inubushi, T. Togashi, T. Sato, J. Kim, R. Fukui, Y. Sano, M. Yabashi, H. Ohashi, T. Ishikawa, and K. Yamauchi, Nat. Commun. 5, 3539 (2014).

5. H. N. Chapman, P. Fromme, A. Barty, T. A. White, R. A. Kirian, A. Aquila, M. S. Hunter, J. Schulz, D. P. DePonte, U. Weierstall, R. B. Doak, F. R. N. C. Maia, A. V. Martin, I. Schlichting, L. Lomb, N. Coppola, R. L. Shoeman, S. W. Epp, R. Hartmann, D. Rolles, A. Rudenko, L. Foucar, N. Kimmel, G. Weidenspointner, P. Holl, M. Liang, M. Barthelmess, C. Caleman, S. Boutet, M. J. Bogan, J. Krzywinski, C. Bostedt, S. Bajt, L. Gumprecht, B. Rudek, B. Erk, C. Schmidt, A. Hömke, C. Reich, D. Pietschner, L. Strüder, G. Hauser, H. Gorke, J. Ullrich, S. Herrmann, G. Schaller, F. Schopper, H. Soltau, K.-U. Kühnel, M. Messerschmidt, J. D. Bozek, S. P. HauRiege, M. Frank, C. Y. Hampton, R. G. Sierra, D. Starodub, G. J. Williams, J. Hajdu, N. Timneanu, M. M. Seibert, J. Andreasson, A. Rocker, O. Jönsson, M. Svenda, S. Stern, K. Nass, R. Andritschke, C.-D. Schröter, F. Krasniqi, M. Bott, K. E. Schmidt, X. Wang, I. Grotjohann, J. M. Holton, T. R. M. Barends, R. Neutze, S. Marchesini, R. Fromme, S. Schorb, D. Rupp, M. Adolph, T. Gorkhover, I. Andersson, H. Hirsemann, G. Potdevin, H. Graafsma, B. Nilsson, and J. C. H. Spence, Nature 470, 73 (2011).

6. M. M. Seibert, T. Ekeberg, F. R. N. C. Maia, M. Svenda, J. Andreasson, O. Jönsson, D. Odić, B. Iwan, A. Rocker, D. Westphal, M. Hantke, D. P. DePonte, A. Barty, J. Schulz, L. Gumprecht, N. Coppola, A. Aquila, M. Liang, T. A. White, A. Martin, C. Caleman, S. Stern, C. Abergel, V. Seltzer, J.-M. Claverie, C. Bostedt, J. D. Bozek, S. Boutet, A. A. Miahnahri, M. Messerschmidt, J. Krzywinski, G. Williams, K. O. Hodgson, M. J. Bogan, C. Y. Hampton, R. G. Sierra, D. Starodub, I. Andersson, S. Bajt, M. Barthelmess, J. C. H. Spence, P. Fromme, U. Weierstall, R. Kirian, M. Hunter, R. B. Doak, S. Marchesini, S. P. Hau-Riege, M. Frank, R. L. Shoeman, L. Lomb, S. W. Epp, R. Hartmann, D. Rolles, A. Rudenko, C. Schmidt, L. Foucar, N. Kimmel, P. Holl, B. Rudek, B. Erk, A. Hömke, C. Reich, D. Pietschner, G. Weidenspointner, L. Strüder, G. Hauser, H. Gorke, J. Ullrich, I. Schlichting, S. Herrmann, G. Schaller, F. Schopper, H. Soltau, K.-U. Kühnel, R. Andritschke, C.-D. Schröter, F. Krasniqi, M. Bott, S. Schorb, D. Rupp, M. Adolph, T. Gorkhover, H. Hirsemann, G. Potdevin, H. Graafsma, B. Nilsson, H. N. Chapman, and J. Hajdu, Nature 470, 78 (2011). 
7. S. Boutet, L. Lomb, G. J. Williams, T. R. M. Barends, A. Aquila, R. B. Doak, U. Weierstall, D. P. DePonte, J. Steinbrener, R. L. Shoeman, M. Messerschmidt, A. Barty, T. A. White, S. Kassemeyer, R. A. Kirian, M. M. Seibert, P. A. Montanez, C. Kenney, R. Herbst, P. Hart, J. Pines, G. Haller, S. M. Gruner, H. T. Philipp, M. W. Tate, M. Hromalik, L. J. Koerner, N. van Bakel, J. Morse, W. Ghonsalves, D. Arnlund, M. J. Bogan, C. Caleman, R. Fromme, C. Y. Hampton, M. S. Hunter, L. Johansson, G. Katona, C. Kupitz, M. Liang, A. V. Martin, K. Nass, L. Redecke, F. Stellato, N. Timneanu, D. Wang, N. A. Zatsepin, D. Schafer, J. Defever, R. Neutze, P. Fromme, J. C. H. Spence, H. N. Chapman, and I. Schlichting, Science 337, 362 (2012).

8. K. Hirata, K. Shinzawa-Itoh, N. Yano, S. Takemura, K. Kato, M. Hatanaka, K. Muramoto, T. Kawahara, T. Tsukihara, E. Yamashita, K. Tono, G. Ueno, T. Hikima, H. Murakami, Y. Inubushi, M. Yabashi, T. Ishikawa, M. Yamamoto, T. Ogura, H. Sugimoto, J.-R. Shen, S. Yoshikawa, and H. Ago, Nat. Meth. 11, 734 (2014)

9. M. Suga, F. Akita, K. Hirata, G. Ueno, H. Murakami, Y. Nakajima, T. Shimizu, K. Yamashita, M. Yamamoto, H. Ago, and J.-R. Shen, Nature 517, 99 (2015).

10. K. Tamasaku, E. Shigemasa, Y. Inubushi, T. Katayama, K. Sawada, H. Yumoto, H. Ohashi, H. Mimura, M. Yabashi, K. Yamauchi, and T. Ishikawa, Nat. Photon. 8, 313 (2014).

11. H. Yoneda, Y. Inubushi, K. Nagamine, Y. Michine, H. Ohashi, H. Yumoto, K. Yamauchi, H. Mimura, H. Kitamura, T. Katayama, T. Ishikawa, M. Yabashi, and M. Yabashi, Nature 524, 446 (2015).

12. W. Zhang, R. Alonso-Mori, U. Bergmann, C. Bressler, M. Chollet, A. Galler, W. Gawelda, R. G. Hadt, R. W. Hartsock, T. Kroll, K. S. Kjær, K. Kubiček, H. T. Lemke, H. W. Liang, D. A. Meyer, M. M. Nielsen, C. Purser, J. S. Robinson, E. I. Solomon, Z. Sun, D. Sokaras, T. B. van Driel, G. Vankó, T. Weng, D. Zhu, and K. J. Gaffney, Nature 509, 345 (2014).

13. J. N. Clark, L. Beitra, G. Xiong, A. Higginbotham, D. M. Fritz, H. T. Lemke, D. Zhu, M. Chollet, G. J. Williams, M. Messerschmidt, B. Abbey, R. J. Harder, A. M. Korsunsky, J. S. Wark, and I. K. Robinson, Science 341, 56 (2013).

14. K. H. Kim, J. G. Kim, S. Nozawa, T. Sao, K. Y. Oang, T. W. Kim, H. Ki, J. Jo, S. Park, C. Song, T. Sato, K. Ogawa, T. Togashi, K. Tono, M. Yabashi, T. Ishikawa, J. Kim, R. Ryoo, J. Kim, H. Ihee, and S. Adachi, Nature 518, 385 (2015).

15. M. P. M. Dean, Y. Cao, X. Liu, S. Wall, D. Zhu, R. Mankowsky, V. Thampy, X. M. Chen, J. G. Vale, D. Casa, J. Kim, A. H. Said, P. Juhas, R. Alonso-Mori, J. M. Glownia, A. Robert, J. Robinson, M. Sikorski, S. Song, M. Kozina, H. Lemke, L. Patthey, S. Owada, T. Katayama, M. Yabashi, Yoshikazu Tanaka, T. Togashi, J. Liu, C. R. Serrao, B. J. Kim, L. Huber, C.-L. Chang, D. F. McMorrow, M. Först, and J. P. Hill, Nat. Mat. 15, 601 (2016)

16. S. M. Vinko, O. Ciricosta, B. I. Cho, K. Engelhorn, H.-K. Chung, C. R. D. Brown, T. Burian, J. Chalupský, R. W. Falcone, C. Graves, V. Hájková, A. Higginbotham, L. Juha, J. Krzywinski, H. J. Lee, M. Messerschmidt, C. D. Murphy, Y. Ping, A. Scherz, W. Schlotter, S. Toleikis, J. J. Turner, L. Vysin, T. Wang, B. Wu, U. Zastrau, D. Zhu, R. W. Lee, P. A. Heimann, B. Nagler, and J. S. Wark, Nature 482, 59 (2012).

17. R. Neutze, R. Wouts, D. van der Spoel, E. Weckert, and J. Hajdu, Nature 406, 752 (2000).

18. A. Barty, C. Caleman, A. Aquila, N. Timneanu, L. Lomb, T. A. White, J. Andreasson, D. Arnlund, S. Bajt, T. R. M. Barends, M. Barthelmess, M. J. Bogan, C. Bostedt, J. D. Bozek, R. Coffee, N. Coppola, J. Davidsson, D. P. DePonte, R. B. Doak, T. Ekeberg, V. Elser, S. W. Epp, B. Erk, H. Fleckenstein, L. Foucar, P. Fromme, H. Graafsma, L. Gumprecht, J. Hajdu, C. Y. Hampton, R. Hartmann, A. Hartmann, G. Hauser,
H. Hirsemann, P. Holl, M. S. Hunter, L. Johansson, S. Kassemeyer, N. Kimmel, R. A. Kirian, M. Liang, F. R. N. C. Maia, E. Malmerberg, S. Marchesini, A. V. Martin, K. Nass, R. Neutze, C. Reich, D. Rolles, B. Rudek, A. Rudenko, H. Scott, I. Schlichting, J. Schulz, M. M. Seibert, R. L. Shoeman, R. G. Sierra, H. Soltau, J. C. H. Spence, F. Stellato, S. Stern, L. Strüder, J. Ullrich, X. Wang, G. Weidenspointner, U. Weierstall, C. B. Wunderer, and H. N. Chapman, Nat. Photonics 6, 35 (2012).

19. I. Inoue, Y. Inubushi, T. Sato, K. Tono, T. Katayama, T. Kameshima, K. Ogawa, T. Togashi, S. Owada, Y. Amemiya, T. Tanaka, T. Hara, and M. Yabashi, Proc. Natl. Acad. Sci. USA 113, 1492 (2016).

20. U. Weierstall, J. C. H. Spence, and R. B. Doak, Rev. Sci. Instrum. 83, 035108 (2012).

21. U. Weierstall, Phil. Trans. R. Soc. B 369, 20130337 (2014).

22. T. R. M. Barends, L. Foucar, S. Botha, R. B. Doak, R. L. Shoeman, K. Nass, J. E. Koglin, G. J. Williams, S. Boutet, M. Messerschmidt, and I. Schlichting, Nature 505, 244 (2014).

23. L. Redecke, K. Nass, D. P. DePonte, T. A. White, D. Rehders, A. Barty, F. Stellato, M. Liang, T. R. M. Barends, S. Boutet, G. J. Williams, M. Messerschmidt, M. M. Seibert, A. Aquila, D. Arnlund, S. Bajt, T. Barth, M. J. Bogan, C. Caleman, T.-C. Chao, R. B. Doak, H. Fleckenstein, M. Frank, R. Fromme, L. Galli, I. Grotjohann, M. S. Hunter, L. C. Johansson, S. Kassemeyer, G. Katona, R. A. Kirian, R. Koopmann, C. Kupitz, L. Lomb, A. V. Martin, S. Mogk, R. Neutze, R. L. Shoeman, J. Steinbrener, N. Timneanu, D. Wang, U. Weierstall, N. A. Zatsepin, J.C. H. Spence, P. Fromme, I. Schlichting, M. Duszenko, C. Betzel, and H. N. Chapman, Science 339, 227 (2013).

24. U. Weierstall, D. James, C. Wang, T. A. White, D. Wang, W. Liu, J. C.H. Spence, R. B. Doak, G. Nelson, P. Fromme, R. Fromme, I. Grotjohann, C. Kupitz, N. A. Zatsepin, H. Liu, S. Basu, D. Wacker, G. W. Han, V. Katritch, S. Boutet, M. Messerschmidt, G. J. Williams, J. E. Koglin, M. M. Seibert, M. Klinker, C. Gati, R. L. Shoeman, A. Barty, H. N. Chapman, R. A. Kirian, K. R. Beyerlein, R. C. Stevens, D. Li, S. T. A. Shah, N. Howe, M. Caffrey, and V. Cherezov, Nat. Commun. 5, 3309 (2014).

25. S. Botha, K. Nass, T. R. M. Barends, W. Kabsch, B. Latz, F. Dworkowski, L. Foucar, E. Panepucci, M. Wang, R. L. Shoeman, I. Schlichting, and R. B. Doak, Acta Cryst. D 47, 387 (2015).

26. W. Liu, D. Wacker, C. Gati, G. W. Han, D. James, D. Wang, G. Nelson, U. Weierstall, V. Katritch, A. Barty, N. A. Zatsepin, D. Li, M. Messerschmidt, S. Boutet, G. J. Williams, J. E. Koglin, M. M. Seibert, C. Wang, S. T. A. Shah, S. Basu, R. Fromme, C. Kupitz, K. N. Rendek, I. Grotjohann, P. Fromme, R. A. Kirian, K. R. Beyerlein, T. A. White, H. N. Chapman, M. Caffrey, J. C. H. Spence, R. C. Stevens, and V. Cherezov, Science 342, 1521 (2013).

27. M. Sugahara, E. Mizohata, E. Nango, M. Suzuki, T. Tanaka, T. Masuda, R. Tanaka, T. Shimamura, Y. Tanaka, C. Suno, K. Ihara, D. Pan, K. Kakinouchi, S. Sugiyama, M. Murata, T. Inoue, K. Tono, C. Song, J. Park, T. Kameshima, T. Hatsui, Y. Joti, M. Yabashi, and S. Iwata, Nat. Meth. 12, 61 (2015).

28. C. E. Conrad, S. Basu, D. James, D. Wang, A. Schaffer, S. Roy-Chowdhury, N. A. Zatsepin, A. Aquila, J. Coe, C. Gati, M. S. Hunter, J. E. Koglin, C. Kupitz, G. Nelson, G. Subramanian, T. A. White, Y. Zhao, J. Zook, S. Boutet, V. Cherezov, J. C. H. Spence, R. Fromme, U. Weierstall, and P. Fromme, IUCrJ 2, 421 (2015).

29. M. Sugahara, C. Song, M. Suzuki, T. Masuda, S. Inoue, T. Nakane, F. Yumoto, E. Nango, R. Tanaka, K. Tono, Y. Joti, T. Kameshima, T. Hatsui, M. Yabashi, O. Nureki, K. Numata, and S. Iwata, Sci. Rep. 6, 24484 (2016). 
30. R. G. Sierra, H. Laksmono, J. Kern, R. Tran, J. Hattne, R. Alonso-Mori, B. Lassalle-Kaiser, C. Glöckner, J. Hellmich, D. W. Schafer, N. Echols, R. J. Gildea, R. W. Grosse-Kunstleve, J. Sellberg, T. A. McQueen, A. R. Fry, M. M. Messerschmidt, A. Miahnahri, M. M. Seibert, C. Y. Hampton, D. Starodub, N. D. Loh, D. Sokaras, T.-C. Weng, P. H. Zwart, P. Glatzel, D. Milathianaki, W. E. White, P. D. Adams, G. J. Williams, S. Boutet, A. Zouni, J. Messinger, N. K. Sauter, U. Bergmann, J. Yano, V. K. Yachandra, and M. J. Bogana, Acta Cryst. D 68, 1584 (2012).

31. F. Mafuné, K. Miyajima, K. Tono, Y. Takeda, J. Kohno, N. Miyauchi, J. Kobayashi, Y. Joti, E. Nango, S. Iwata, and M. Yabashi, Acta Cryst. D 72, 520 (2016).

32. C. G. Roessler, R. Agarwal, M. Allaire, R. Alonso-Mori, B. Andi, J. F. R. Bachega, M. Bommer, A. S. Brewster, M. C. Browne, R. Chatterjee, E. Cho, A. E. Cohen, M. Cowan, S. Datwani, V. L. Davidson, J. Defever, B. Eaton, R. Ellson, Y. Feng, L. P. Ghislain, J. M. Glownia, G. Han, J. Hattne, J. Hellmich, A. Héroux, M. Ibrahim, J. Kern, A. Kuczewski, H. T. Lemke, P. Liu, L. Majlof, W. M. McClintock, S. Myers, S. Nelsen, J. Olechno, A. M. Orville, N. K. Sauter, A. S. Soares, S. M. Soltis, H. Song, R. G. Stearns, R. Tran, Y. Tsai, M. Uervirojnangkoorn, C. M. Wilmot, V. Yachandra, J. Yano, E. T. Yukl, D. Zhu, and A. Zouni, Structure 24, 631 (2016).

33. D. Wang, U. Weierstall, L. Pollack, and J. C. H. Spence, J. Synchrotron Radiat. 21, 1364 (2014).

34. G. D. Calvey, A. M. Katz, C. B. Schaffer, and L. Pollack, Struct. Dyn. 3, 054301 (2016).

35. N. D. Loh, C. Y. Hampton, A. V. Martin, D. Starodub, R. G. Sierra, A. Barty, A. Aquila, J. Schulz, L. Lomb, J. Steinbrener, R. L. Shoeman, S. Kassemeyer, C. Bostedt, J. Bozek, S. W. Epp, B. Erk, R. Hartmann, D. Rolles, A. Rudenko, B. Rudek, L. Foucar, N. Kimmel, G. Weidenspointner, G. Hauser, P. Holl, E. Pedersoli, M. Liang, M. S. Hunter, L. Gumprecht, N. Coppola, C. Wunderer, H. Graafsma, F. R. N. C. Maia, T. Ekeberg, M. Hantke, H. Fleckenstein, H. Hirsemann, K. Nass, T. A. White, H. J. Tobias, G. R. Farquar, W. H. Benner, S. P. Hau-Riege, C. Reich, A. Hartmann, H. Soltau, S. Marchesini, S. Bajt, M. Barthelmess, P. Bucksbaum, K. O. Hodgson, L. Strüder, J. Ullrich, M. Frank, I. Schlichting, H. N. Chapman, and M. J. Bogan, Nature 486, 513 (2012).

36. K. Tono, T. Togashi, Y. Inubushi, T. Sato, T. Katayama, K. Ogawa, H. Ohashi, H. Kimura, S. Takahashi, K. Takeshita, H. Tomizawa, S. Goto, T. Ishikawa, and M. Yabashi, New J. Phys. 15, 083035 (2013).

37. P. Schmüser, M. Dohlus, J. Rossbach, and C. Behrens, in FreeElectron Lasers in the Ultraviolet and $X$-ray Regime, 2nd edn (Springer, Switzerland, 2014), p. 165.

38. M. Yabashi, H. Tanaka, and T. Ishikawa, J. Synchrotron Rad. 22, 477 (2015)

39. I. Inoue, K. Tono, Y. Joti, T. Kameshima, K. Ogawa, Y. Shinohara, Y. Amemiya, and M. Yabashi, IUCrJ 2, 620 (2015).

40. K. Yamashita, D. Pan, T. Okuda, M. Sugahara, A. Kodan, T. Yamaguchi, T. Murai, K. Gomi, N. Kajiyama, E. Mizohata, M. Suzuki, E. Nango, K. Tono, Y. Joti, T. Kameshima, J. Park, C. Song, T. Hatsui, M. Yabashi, S. Iwata, H. Kato, H. Ago, M. Yamamoto, and T. Nakatsu, Sci. Rep. 5, 14017 (2015).
41. T. Nakane, C. Song, M. Suzuki, E. Nango, J. Kobayashi, T. Masuda, S. Inoue, E. Mizohata, T. Nakatsu, T. Tanaka, R. Tanaka, T. Shimamura, K. Tono, Y. Joti, T. Kameshima, T. Hatsui, M. Yabashi, O. Nureki, S. Iwata, and M. Sugahara, Acta Cryst. D 71, 2519 (2015).

42. Y. Fukuda, K. M. Tse, T. Nakane, T. Nakatsu, M. Suzuki, M. Sugahara, S. Inoue, T. Masuda, F. Yumoto, N. Matsugaki, E. Nango, K. Tono, Y. Joti, T. Kameshima, C. Song, T. Hatsui, M. Yabashi, O. Nureki, M. E. P. Murphy, T. Inoue, S. Iwata, and E. Mizohata, Proc. Natl. Acad. Sci. USA 113, 2928 (2016).

43. K. Tono, E. Nango, M. Sugahara, C. Song, J. Park, T. Tanaka, R. Tanaka, Y. Joti, T. Kameshima, S. Ono, T. Hatsui, E. Mizohata, M. Suzuki, T. Shimamura, Y. Tanaka, S. Iwata, and M. Yabashi, J. Synchrotron Rad. 22, 532 (2015).

44. T. Kameshima, S. Ono, T. Kudo, K. Ozaki, Y. Kirihara, K. Kobayashi, Y. Inubushi, M. Yabashi, T. Horigome, A. Holland, K. Holland, D. Burt, H. Murao, and T. Hatsui, Rev. Sci. Instrum. 85, 033110 (2014).

45. C. Song, K. Tono, J. Park, T. Ebisu, S. Kim, H. Shimada, S. Kim, M. Gallagher-Jones, D. Nam, T. Sato, T. Togashi, K. Ogawa, Y. Joti, T. Kameshima, S. Ono, T. Hatsui, S. Iwata, M. Yabashi, and T. Ishikawa, J. Appl. Cryst. 47, 188 (2014).

46. D. P. DePonte, U. Weierstall, K. Schmidt, J. Warner, D. Starodub, J. C. H. Spence, and R. B. Doak, J. Phys. D: Appl. Phys. 41, 195505 (2008).

47. D. P. DePonte, R. B. Doak, M. Hunter, Z. Liuc, U. Weierstall, and J. C. H. Spence, Micron 40, 507 (2009).

48. D. P. DePonte, J. T. Mckeown, U. Weierstall, R. B. Doak, and J. C. H. Spence, Ultramicroscopy 111, 824 (2011).

49. E. Nango, et al., to be submitted.

50. D. A. Sherrell, A. J. Foster, L. Hudson, B. Nutter, J. O'Hea, S. Nelson, O. Paré-Labrosse, S. Oghbaey, R. J. D. Miller, and R. L. Owen, J. Synchrotron Rad. 22, 1372 (2015).

51. M. Heymann, A. Opathalage, J. L. Wierman, S. Akella, D. M. E. Szebenyi, S. M. Gruner, and S. Fraden, IUCrJ 1349 (2014).

52. A. Y. Lyubimov, T. D. Murray, A. Koehl, I. E. Araci, M. Uervirojnangkoorn, O. B. Zeldin, A. E. Cohen, S. M. Soltis, E. L. Baxter, A. S. Brewster, N. K. Sauter, A. T. Brunger, and J. M. Berger, Acta Cryst. D 71, 928 (2015).

53. T. R. M. Barends, L. Foucar, A. Ardevol, K. Nass, A. Aquila, S. Botha, R. B. Doak, K. Falahati, E. Hartmann, M. Hilpert, M. Heinz, M. C. Hoffmann, J. Köfinger, J. E. Koglin, G. Kovacsova, M. Liang, D. Milathianaki, H. T. Lemke, J. Reinstein, C. M. Roome, R. L. Shoeman, G. J. Williams, I. Burghardt, G. Hummer, S. Boutet, and I. Schlichting, Science 350, 445 (2015).

54. K. Pande, C. D. M. Hutchison, G. Groenhof, A. Aquila, J. S. Robinson, J. Tenboer, S. Basu, S. Boutet, D. P. DePonte, M. Liang, T. A. White, N. A. Zatsepin, O. Yefanov, D. Morozov, D. Oberthuer, C. Gati, G. Subramanian, D. James, Y. Zhao, J. Koralek, J. Brayshaw, C. Kupitz, C. Conrad, S. RoyChowdhury, J. D. Coe, M. Metz, P. L. Xavier, T. D. Grant, J. E. Koglin, G. Ketawala, R. Fromme, V. Šrajer, R. Henning, J. C. H. Spence, A. Ourmazd, P. Schwander, U. Weierstall, M. Frank, P. Fromme, A. Barty, H. N. Chapman, K. Moffat, J. J. van Thor, and M. Schmidt, Science 352, 725 (2016). 